Jurnal Basicedu Volume 4 Nomor 2 April 2020 Hal.295-305

JURNAL BASICEDU

Research \& Learning in Elementary Education

https://jbasic.org/index.php/basicedu

\title{
Peningkatan AKtivitas Belajar Siswa melalui Model Think Pair Share di Sekolah Dasar
}

\author{
Maria Ratna Sariayu ${ }^{1}$, Yalvema Miaz \\ Universitas Negeri Padang, Sumatera Barat, Indonesia \\ E-mail : mariasariayu023@gmail.com, yalmiaz@gmail.com²
}

\begin{abstract}
Abstrak
Penelitian ini dilatarbelakangi oleh rendahnya aktivitas siswa kelas IV dalam pembelajaran IPS di SD Setia Padang. Tujuan dari penelitian ini adalah untuk meningkatkan aktivitas siswa di kelas IV dalam belajar ilmu sosial melalui model Think Pair Share sekolah dasar Setia Padang. Penelitian ini dilakukan dengan menggunakan penelitian tindakan kelas yang dilakukan dalam dua siklus. Subjek penelitian ini adalah siswa kelas IV Sekolah Dasar Setia Padang yang menguji 25 orang. Instrumen yang digunakan adalah lembar observasi aktivitas siswa, lembar observasi aktivitas guru, catatan lapangan, dan tes prestasi belajar. Berdasarkan analisis aktivitas siswa dalam setiap siklus peningkatan efisiensi. Pada siklus pertama 45,33\% meningkat menjadi 74,66\%. Dari hasil penelitian ini disimpulkan bahwa ada peningkatan aktivitas siswa di kelas IV dalam belajar ilmu sosial melalui model Think Pair Share di Share sekolah dasar Setia Padang.
\end{abstract}

Kata kunci :, Ilmu Sosial, Kegiatan, Hasil Belajar, Model Think Pair Share.

\begin{abstract}
Abstrack
This research is motivated by the low activity of grade IV students in the social science lessons at Setia Padang Elementary School. The purpose of this study is to improve the activities of students in class IV in learning social science through the Think Pair Share the Primary School Setia model. This research was conducted using classroom action research conducted in two cycles. The subjects of this study were the IV grade students of Setia Padang Elementary School who tested 25 people. The instruments used were student activity observation sheets, teacher activity observation sheets, field notes, and learning achievement tests. Based on an analysis of student activity in each cycle of efficiency improvements. In the first cycle $45.33 \%$ increased to $74.66 \%$. From the results of this study it was concluded that there was an increase in student activity in class IV in learning social science through the Think Pair Share model in Setia Padang Elementary School.
\end{abstract}

Keyword:, Social Studies, Activities,Results Learning, Think Pair Share Model.

@ Jurnal Basicedu 2020

$\triangle$ Corresponding author :

Address :-

ISSN 2580-3735 (Media Cetak)

Email :-

ISSN 2580-1147 (Media Online)

Phone :- 
296 Peningkatan Aktivitas Belajar Siswa melalui Model Think Pair Share di Sekolah Dasar - Maria Ratna Sariayu, Yalvema Miaz

\section{PENDAHULUAN}

Tema pendidikan selalu menarik dibahas. Kemenarikannya mendorong banyak pihak untuk membahasnya baik dalam diskusi, seminar, dan lokakarya maupun penelitian. Apalagi bagi institusi pendidikan yang menyiapkan para mahasiswanya menjadi calon praktisi pendidikan, tema ini sudah menjadi bagian yang tidak dapat dipisahkan. Lebih khusus lagi bagi para calon praktisi tersebut karena mereka akan menjalankan dan mengalami langsung aktivitas pendidikan di lapangan.

Pendidikan adalah usaha yang sengaja dan terencana untuk membantu perkembangan potensi dan kemampuan peserta didik agar bermanfaat bagi kepentingan hidupnya sebagai seorang individu dan sebagai warga negara atau masyarakat, dengan memilih isi (materi), strategi kegiatan, dan teknik penilaian yang sesuai (Suryosubroto,2010:2). Kesadaran itu diperkuat pula oleh pengamatan dan pengalaman bahwa guru dan tenaga kependidikan adalah pemimpin, pengelola, dan penyelenggara pendidikan.

Pendidikan adalah investasi jangka panjang yang memerlukan usaha dan dana yang cukup besar. Proses belajar yang diselenggarakan di lingkungan pendidikan formal atau sekolah tidak lain dimaksudkan untuk mengarahkan perubahan pada diri siswa secara terencana baik dalam aspek pengetahuan, keterampilan dan sikap dalam seluruh proses pendidikan di sekolah. (Situmorang, 2018).

\section{Berdasarkan pemahaman tersebut,} pendidikan pada dasarnya adalah proses penyiapan subjek didik menuju manusia masa depan yang bertanggung jawab. Agar tujuan dan sasaran pendidikan dapat tercapai maka dibutuhkan perbaikan kualitas pengajaran dan pembelajaran sebagai implementasi nyata pendidikan di tingkat sekolah, kelas, dan mata pelajaran.
Secara konkret perbaikan tersebut diwujudkan melalui perbaikan mutu pembelajaran sebagai proses yang dapat menumbuhkan daya tangkap, daya serap, dan daya tanggap serta berbudi pekerti seperti tampak melalui rasa percaya diri, sikap dan prilaku yang kreatif dan inovatif peserta didik.

Agar pelajaran IPS lebih berkesan bagi siswa, maka haruslah diciptakan suasana belajar yang menyenangkan. Pembelajaran IPS harus disajikan secara interaktif yaitu pembelajaran yang dapat membangkitkan minat, perhatian dan motivasi siswa untuk belajar karena topik- topik dalam pembelajaran IPS dekat dengan diri siswa.(Miaz, 2012)

Ilmu pengetahuan sosial adalah salah satu mata pelajaran yang strategis untuk membentuk sosok peserta didik yang didambakan tersebut. Konten sikap, pengetahuan, dan keterampilan yang menjadi muatan mata pelajaran ini diusahakan untuk membantu dan melatih perserta didik untuk menampilkan sikap, menyerap pengetahuan, dan terampil menerapkannya baik sebagai pribadi dalam masyarakat maupun sebagai warga yang peduli terhadap persoalan kemasyarakatan dari berbagai sudut pandang secara komprehensif (Supardan, 2015:17).

(Yalvema, 2012) menjelaskan IPS bertujuan membina peserta didik menjadi warga negara yang baik yang memiliki pengetahuan, keterampilan dan kepedulian sosial yang berguna bagi dirinya sendiri serta bagi masyarakat dan negara.

Pemilihan model pembelajaran yang sesuai dengan tujuan kurikulum dan potensi siswa merupakan kemampuan dan keterampilan dasar yang harus dimiliki oleh seorang guru. Hal ini didasari asumsi bahwa ketepatan guru dalam memilih model pembelajaran akan berpengaruh terhadap hasil belajar siswa. Model pembelajaran 
yang digunakan oleh guru berpengaruh terhadap kualitas proses belajar mengajar yang dilakukannya. (Ketut, 2018)

Pembelajaran kooperatif sangat cocok untuk siswa karena akan lebih mudah menemukan dan memahami konsep yang sulit jika mereka saling berdiskusi dengan temannya siswa secara rutin bekerja dalam kelompok untuk saling membantu dalam memecahkan masalah-masalah yang kompleks.

Dalam pembelajaran kooperatif terdapat beberapa macam tekhnik pembelajaran, salah satunya yaitu pembelajaran kooperatif tipe thinkpair-share. Model pembelajaran kooperatif tipe think-pair-share ini memiliki keunggulan yaitu siswa dapat banyak waktu untuk berfikir, merespon, dan saling membantu, guru hanya menyampaikan materi secara singkat, kemudian mengajukan pertanyaan, kemudian guru menginginkan siswa memikirkan secara lebih mendalam tentang materi yang telah dijelaskan dan dialami. (Tarbiyah, 2011).

Peneliti melakukan studi pendahuluan melalui pengamatan dan wawancara tidak terstruktur dan membaca dokumen seperti data kolektif hasil penilaian mata pelajaran IPS. Berdasarkan studi pendahuluan tersebut ditemukan beberapa masalah, seperti masih banyak model pembelajaran yang bersifat konvensional, belum tampaknya inovasi dan improvisasi serta kurangnya partisipasi siswa dalam pembelajaran. Selain berdampak pada proses, masalah-masalah tersebut mempengaruhi hasil belajar siswa sebagaimana terbukti dari nilai siswa.

Berdasarkan pengamatan sekilas ditemukan bahwa pelaksanaan pembelajaran ilmu pengetahuan sosial dirasakan cukup membosankan bagi siswa siswi kelas IV SD Setia karena metode yang digunakan oleh guru bersifat konvensional. Hal-hal tersebut tampak dalam perilaku peserta didik yang kurang konsentarasi, cenderung bermain saat guru sedang mengajar, dan riang gembira saat pelajaran usai. Fenomena-fenomena tersebut menunjukkan bahwa para siswa kurang betah dan merasa pembelajaran yang sedang berlangsung membosankan

Rendahnya hasil belajar ilmu pengetahuan sosial siswa kelas IV SD Setia dipengaruhi faktor guru itu sendiri, seperti metode yang digunakan guru tidak bervariasi sehingga suasana belajar di kelas kurang menyenangkan dan penggunaan model pembelajaran yang bersifat konvensional sehingga berpengaruh terhadap hasil belajar siswa. Faktor-faktor tersebut menyebabkan pembelajaran membosankan, kurang efektif untuk menarik perhatian dan keaktifan peserta didik dalam proses belajar mengajar.

Pada pendekataan konvensional ini guru menjelaskan materi pelajaran terlebih dahulu, setelah itu siswa berkelompok untuk berdiskusi. Sebelum diskusi dimulai, guru membagi 5 kelompok, masing-masing kelompok terdiri 5 siswa dan menugaskan siswa untuk menyusun meja. Sewaktu menyusun meja siswa meribut dan banyak menghabiskan waktu. Hanya 7 orang dari 25 orang siswa yang aktif dalam diskusi jika di persentasekan menjadi $28 \%$ dan tidak ada kelompok yang mempresentasikan diskusi. Berikut ini rincian proses berdiskusi siswa kelas IV pada pembelajaran IPS dalam bertanya sebanyak 5 siswa dari 25 jumlah siswa keseluruhan jika di persentasekan $20 \%$, yang menjawab pertanyaan 5 siswa dari 25 jumlah siswa keseluruhan jika di persentasekan $20 \%$. Kondisi ini berakibat buruk pada hasil ulangan harian 1 semester II pada tema 2 kd 3.1 IPS Tahun Ajaran 2018/2019. Kriteria Ketuntasan Minimal (KKM) yang ditetapkan oleh sekolah tersebut khususnya untuk kd 3.1 mata pelajaran IPS adalah 70 . 
Di latar belakangi oleh kondisi riil di sekolah sebagaimana yang telah di deskripsikan, peneliti tertarik untuk memecahkan masalah dengan melakukan penelitian tindakan kelas (PTK) dengan judul: "Peningkatan Aktivitas Siswa Kelas IV pada Pembelajaran IPS melalui model Think Pair Share di SD Setia Padang”.

\section{METODE}

Jenis penelitian ini adalah jenis penelitian tindakan kelas yaitu penelitian yang dilakukan oleh guru dalam kelasnya sendiri melalui refleksi diri, dengan tujuan untuk memperbaiki kinerjanya sebagai pendidik sehingga hasil belajar peserta didik meningkat.

Penelitian ini telah dilaksanakan di kelas IV SD Setia Padang, Kecamatan Koto Tangah, Provinsi Sumatera Barat. Subjek dalam penelitian ini adalah siswa kelas IV Tahun Ajaran 2018/2019 SD Setia Padang, yang mana jumlah siswanya 25 orang, yang terdiri dari laki-laki berjumlah 12 orang dan perempuan berjumlah 13 orang.

Penelitian ini dilaksanakan pada semester II, terhitung mulai dari waktu perencanaan sampai penelitian laporan hasil penelitian. Penelitian ini dilakukan dengan mengacu pada disain PTK yang dirumuskan oleh Arikunto, Suharsimi, dkk. (2010:16) yang terdiri dari empat komponen, yaitu: perencanaan, pelaksanaan tindakan, pengamatan, dan refleksi.

Indikator keberhasilan pada penelitian ini adalah:

1. Aktivitas siswa dalam diskusi meningkat dari $28 \%$ mencapai $78 \%$.

2. Aktivitas siswa dalam bertanya dan menjawab pertanyaan meningkat dari $20 \%$ mencapai $70 \%$.

3. Aktivitas siswa dalam memberikan kesimpulan meningkat dari $20 \%$ mencapai $70 \%$.

Data dalam penelitian ini berupa data kualitatif. Data kualitatif ini diperoleh dari hasil wawancara disekolah. Sumber data adalah siswa kelas IV yang menjadi responden penelitian. Data tersebut adalah data berupa informasi yang meliputi aktivitas siswa dalam proses pembelajaran.

Data primer mencakup data aktivitas belajar siswa, tes hasil belajar, berupa nilai Ulangan Harian (UH), dan aktivitas guru dalam melaksanakan pembelajaran IPS dengan model Think Pair Share. Data sekunder yang akan digunakan dalam penelitian ini adalah nilai U.H semester II, dan nilai mid semester siswa kelas IV SD Setia Padang.

Adapun teknik pengumpulan data dalam penelitian ini dapat dilihat pada di bawah ini:

1. Observasi

a) Lembar observasi aktivitas guru, untuk menganalisis pelaksanaan aktivitas guru sesuai dengan kegiatan pembelajaran (deskriptor) dalam pembelajaran IPS, dan harus memperhitungkan atau mempertimbangkan bobot kualifikasi yang ada dari setiap deskriptor.

b) Lembar pengamatan aktivitas siswa untuk mengamati aktivitas belajar siswa dalam diskusi, bertanya dan menjawab pertanyaan, dan aktivitas siswa dalam memberikan kesimpulan.

2. Dokumentasi

a) Dokumentasi dilaksanakan untuk membuktikan data mengenai aktivitas siswa itu diperoleh.

b) Lembar tes hasil belajar siswa.

c) Photo untuk melengkapi data lapangan yang terjadi apabila ada hal-hal yang terlepas dari pengamatan peneliti pada saat observasi terutama pada saat siswa beraktivitas dalam proses pembelajaran IPS.

d) Pencatatan lapangan digunakan untuk mendokumentasikan kejadian-kejadian selama 
pembelajaran berlangsung, yaitu dari awal pembelajaran sampai akhir pembelajaran melalui model Think Pair Share.

3. Tes hasil belajar

Tes hasil belajar berupa tes akhir siklus digunakan untuk mengukur ataupun mengetahui kemampuan siswa dalam memahami materi pembelajaran IPS dengan model Think Pair Share.

Data yang diperoleh dalam penelitian ini akan dianalisis dengan menggunakan metode kualitatif yang mengacu kepada teknik pengumpulan data penelitian kualitatif yang dirancang oleh Sunafiah Faisal (dalam Bungin, 2003:70). Tahap analisis data tersebut diuraikan sebagai berikut:

1. Menelaah data yang telah terkumpul baik melalui observasi pencatatan dengan menggunakan proses hasil pengamatan, penyeleksian dan pemilihan data. Hal ini misalnya mengelompokkan data pada siklus I, dan siklus II. Kegiatan menelaah data dilaksanakan sejak awal. aktivitas siswa dalam memberikan kesimpulan meningkat dari $20 \%$ menjadi $70 \%$. Setelah diadakan kuis pada akhir pembelajaran maka nilai ata-rata siswa naik $70 \%$ di atas KKM yang telah ditetapkan di sekolah tersebut yaitu 70. Jika halhal di atas bisa tercapai, maka penggunaan model

Think Pair Share dapat dikatakan bisa meningkatkan aktivitas siswa dalam pembelajaran IPS kelas IV SD Setia Padang.

Untuk menganalisis proses pembelajaran, digunakan:

\section{Aktivitas Guru}

Data aktivitas guru dilihat dari kegiatan pembelajaran yang dilakukan guru yang dibuat dalam bentuk lembaran observasi guru. Di sini peneliti mengamati guru mulai dari kegiatan pendahuluan, kegiatan inti, kegiatan penutup. Peneliti menulis data lembar observasi dan memberikan peniaian berdasarkan cara mengajar yang disajikan oleh guru. Penilaian aktivitas guru menurut Desfitri, dkk (2008:40), menggunakan pedoman sebagai berikut:

2. Reduksi data, meliputi pengkategorian dan Persentase perolehan skor $\frac{\text { jumlah skor guru }}{\text { skor maksimum }} \times 100 \%$ pengklasifikasian. Semua data yang terkumpul diseleksi dan dikelompokkan sesuai dengan pusatnya.

3. Menyajikan data dilakukan dengan cara mengorganisir informasi yang telah direduksi. Data tersebut mula-mula disajikan terpisah, tetapi setelah tindakan terakhir akan dilakukan reduksi. Keseluruhan data tindakan dirangkum dan disajikan secara terpadu sehingga diperoleh sajian tunggal berdasarkan fokus pembelajaran dengan model Think Pair Share.

Hasil analisis dalam meningkatkan aktivitas siwa dalam pembelajaran PKn dinyatakan berhasil apabila aktivitas siswa dalam diskusi meningkat dari $28 \%$ menjadi $78 \%$ dari sebelumnya, aktivitas bertanya dan menjawab pertanyaan meningkat dari $20 \%$ menjadi $70 \%$, dan

$$
\begin{aligned}
& \text { Kriteria taraf keberhasilan: } \\
& \begin{array}{ll}
76 \%-100 \% & =\text { Baik } \\
51 \%-75 \% & =\text { Cukup baik } \\
26 \%-50 \% & =\text { Kurang baik } \\
0-25 \% & =\text { Tidak baik }
\end{array}
\end{aligned}
$$

\section{Aktivitas Siswa}

Data aktivitas siswa dapat dibuat dalam bentuk lembaran aktivitas siswa, yang mana peneliti mengamati seluruh siswa dan kegiatan yang dilakukan siswa dalam proses pembelajaran. Peneliti juga menuliskan hasil penelitiannya pada lembar observasi. Penilaian aktivitas siswa menurut Desfitri, dkk (2008:41), menggunakan pedoman sebagai berikut:

$\mathrm{P}=\frac{\text { jumlah siswa melakukan indikator }}{\text { jumlah siswa seluruhnya }} \times 100 \%$

Keterangan: 
300 Peningkatan Aktivitas Belajar Siswa melalui Model Think Pair Share di Sekolah Dasar - Maria Ratna Sariayu, Yalvema Miaz

$\mathrm{P}=$ Persentase siswa yang aktif dalam indikator.

Penilaian aktivitas siswa menurut Dimyati dan Mudjono (dalam Desfitri, 2008:41), menggunakan pedoman sebagai berikut:

$1 \%-25 \%=$ Sedikit sekali

$26 \%-50 \%=$ Sedikit

$51 \%-75 \%=$ Banyak

$76 \%-99 \%=$ Banyak sekali

Analisis hasil belajar siswa yang digunakan adalah tes hasil belajar berupa tes akhir siklus untuk melihat adanya peningkatan hasil belajar siswa dalam pembelajaran IPS dengan menggunakan tipe Think Pair Share. Rumus untuk data hasil belajar menurut Desfitri, dkk (2008:4344), adalah:

a. Nilai rata-rata hasil belajar siswa

$\mathrm{X}=\frac{\sum x}{n}$

Keterangan:

$\mathrm{X}=$ Nilai rata-rata.

$\sum \mathrm{X}=$ Jumlah nilai seluruh peserta didik.

$n \quad=$ Jumlah seluruh peserta didik.

b. Ketuntasan belajar siswa secara klasikal.

$\mathrm{TB}=\frac{S}{N} x 100$

Keterangan:

$\mathrm{TB}=$ Ketuntasan belajar secara klasikal.

$\mathrm{S}=$ Jumlah siswa yang memperoleh nilai $\geq 70$.

$\mathrm{N}=$ Jumlah seluruh siswa.

\section{HASIL PENELITIAN DAN PEMBAHASAN}

Data hasil observasi ini didapatkan melalui lembar observasi aktivitas siswa, dan digunakan untuk melihat proses dan perkembangan aktivitas yang terjadi selama pembelajaran berlangsung. Indikator aktivitas siswa yang diobservasi adalah: aktivitas siswa dalam diskusi, aktivitas siswa dalam bertanya dan menjawab pertanyaan, dan aktivitas siswa dalam memberikan kesimpulan.
Hasil analisis aktivitas belajar siswa terhadap pembelajaran IPS dapat dilihat pada tabel 1 berikut

Tabel 01. Data Hasil Aktivitas Siswa

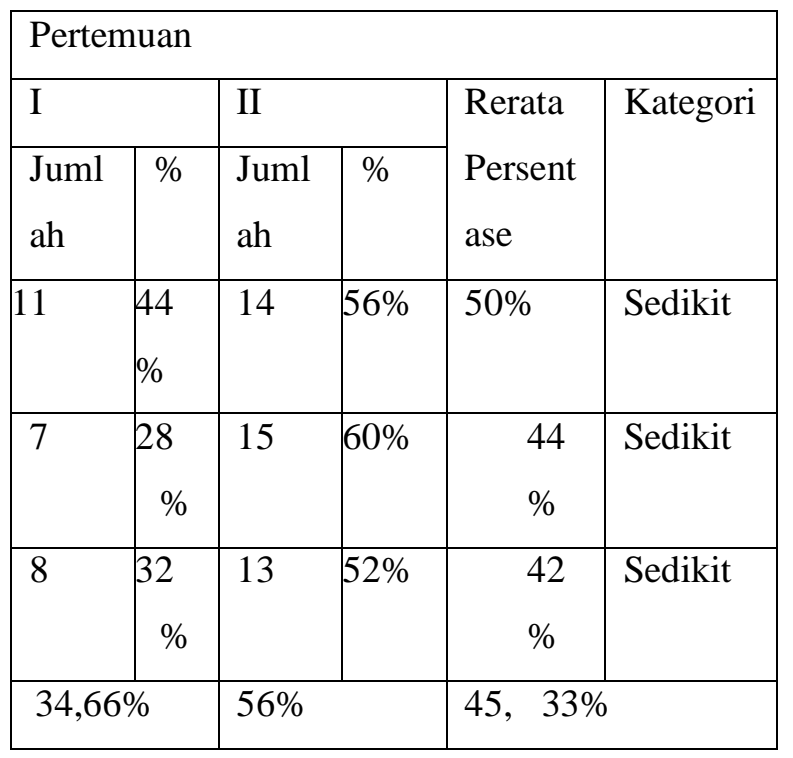

Berdasarkan tabel di atas dijelaskan sebagai berikut: Siswa yang berdiskusi pada pertemuan 1 berjumlah 11 orang dengan persentase $44 \%$ dan pada pertemuan 2 terjadi peningkatan yaitu sebanyak 14 orang yang berdiskusi dengan persentase sebesar 56\%, dari kedua hasil indikator tersebut di dapat rata-rata persentase sebesar $50 \%$. Meskipun terjadi peningkatan, akan tetapi peningkatan tersebut belum mencapai nilai $70 \%$ yang telah di tetapkan.

Siswa yang bertanya dan menjawab pertanyaan pada pertemuan 1 berjumlah 7 orang dengan persentase $28 \%$, sedangkan pada pertemuan 2 siklus I siswa bertanya dan menjawab pertanyaan berjumlah 15 orang dengan persentase $60 \%$. Jadi diperoleh rata-rata persentase $44 \%$ dalam kategori sedikit.

Siswa yang memberikan kesimpulan pada pertemuan 1 siklus I berjumlah 8 orang dengan persentase $32 \%$, sedangkan pada pertemuan 2 siklus I siswa yang memberikan kesimpulan berjumlah 13 orang dengan persentase $52 \%$. Jadi 
301 Peningkatan Aktivitas Belajar Siswa melalui Model Think Pair Share di Sekolah Dasar - Maria Ratna Sariayu, Yalvema Miaz

diperoleh rata-rata persentase $42 \%$ dalam kategori sedikit.

\section{Data Hasil Observasi Aktivitas Guru}

Berdasarkan lembar observasi aktivitas guru dalam pembelajaran pada siklus I, maka jumlah skor dan persentase aktivitas guru dalam mengelola pembelajaran pada siklus I dapat dilihat pada table berikut:

Table 02.

Persentase hasil observasi aktivitas guru pada siklus I

\begin{tabular}{|l|l|l|l|l|}
\hline $\begin{array}{l}\text { Pertemu } \\
\text { an }\end{array}$ & $\begin{array}{l}\text { Skor } \\
\text { Maksi } \\
\text { mal }\end{array}$ & $\begin{array}{l}\text { Jumla } \\
\text { h skor }\end{array}$ & $\begin{array}{l}\text { Persent } \\
\text { ase }\end{array}$ & $\begin{array}{l}\text { Kategor } \\
\text { i }\end{array}$ \\
\hline 1 & 80 & 58 & $72,5 \%$ & Baik \\
\hline 2 & 80 & 63 & $\begin{array}{l}78,75 \\
\%\end{array}$ & Baik \\
\hline Rata-rata & 60,5 & $\begin{array}{l}75,63 \\
\%\end{array}$ & Baik \\
\hline
\end{tabular}

Berdasarkan tabel di atas, dapat dilihat bahwa persentase guru dalam mengelola pembelajaran memiliki rata-rata persentase 75,63 $\%$. Dengan melihat persentase aktivitas guru saat pembelajaran dapat diasumsikan bahwa kegiatan pembelajaran yang dilakukan oleh guru baik.

\section{Data Hasil Belajar pada Ujian Akhir Siklus I}

Berdasarkan hasil belajar tes siklus I terkait ujian akhir siklus, persentase siswa yang tuntas ujian akhir siklus dan rata-rata skor tesnya dapat dilihat pada tabel berikut:
Tabel 03.

Rata-Rata Tes Hasil Belajar Siswa Pada Siklus I

\begin{tabular}{|c|c|c|c|}
\hline No & Uraian & Jumlah & persentase \\
\hline 1. & $\begin{array}{l}\text { Jumlah siswa } \\
\text { yang } \\
\text { mengikuti tes }\end{array}$ & 22 & $88 \%$ \\
\hline 2. & $\begin{array}{ll}\text { Jumlah } & \text { siswa } \\
& \\
\text { yang } & \text { tuntas } \\
\text { belajar } & \end{array}$ & 6 & $24 \%$ \\
\hline 3. & $\begin{array}{l}\text { Jumlah siswa } \\
\text { yang tidak } \\
\text { tuntas belajar }\end{array}$ & 19 & $76 \%$ \\
\hline 4. & $\begin{array}{l}\text { persentase } \\
\text { ketuntasan } \\
\text { belajar siswa }\end{array}$ & $24 \%$ & \\
\hline 5. & $\begin{array}{l}\text { Rata-rata skor } \\
\text { siswa }\end{array}$ & 44 & \\
\hline
\end{tabular}

Dari analisis data di atas, dapat dilihat bahwa hasil belajar siswa pada ujian akhir siklus I, tampak secara klasikal rata-rata hasil tes siswa yang hadir pada siklus I 24\%, menunjukan hasil belajar siswa masih kurang. Dari 22 orang siswa yang mengikuti tes hanya 6 orang yang mendapat nilai di atas KKM, atau jika dipersentasekan hanya $24 \%$, sedangkan indikator keberhasilan di tetapkan $70 \%$. Sedangkan siswa yang tidak tuntas atau di bawah KKM 75 sebanyak 19 orang atau jika dipersentasekan 76\%. Rata-rata nilai juga masih rendah yaitu 44. Rata-rata nilai ini masih berada di bawah KKM. Dengan demikian dapat dikatakan bahwa pada siklus I ketuntasan belajar secara klasikal belum tercapai target yang diharapkan yaitu $70 \%$. 
302 Peningkatan Aktivitas Belajar Siswa melalui Model Think Pair Share di Sekolah Dasar - Maria Ratna Sariayu, Yalvema Miaz

Tabel 04.

Jumlah dan Persentase Aktivitas Siswa pada Siklus II

\begin{tabular}{|c|c|c|c|c|c|}
\hline \multicolumn{6}{|c|}{ Pertemuan } \\
\hline \multicolumn{2}{|l|}{ I } & \multicolumn{2}{|l|}{ II } & \multirow{2}{*}{$\begin{array}{l}\text { Rerata } \\
\text { Present } \\
\text { ase }\end{array}$} & \multirow[t]{2}{*}{ Kategori } \\
\hline umlah & $\%$ & Jumlah & $\%$ & & \\
\hline $\begin{array}{l}1 \\
9\end{array}$ & $76 \%$ & 20 & $\begin{array}{r}80 \\
\%\end{array}$ & & $\begin{array}{l}\text { Banyak } \\
\text { sekali }\end{array}$ \\
\hline $\begin{array}{l}1 \\
7\end{array}$ & $68 \%$ & 18 & $\begin{array}{l}72 \\
\%\end{array}$ & & Banyak \\
\hline $\begin{array}{l}1 \\
8\end{array}$ & $72 \%$ & 20 & $\begin{array}{l}80 \\
\%\end{array}$ & & Banyak \\
\hline \multicolumn{2}{|l|}{$72 \%$} & $77,33 \%$ & & \multicolumn{2}{|c|}{$74,66 \%$} \\
\hline
\end{tabular}

Berdasarkan tabel di atas dijelaskan sebagai berikut: Siswa yang berdiskusi pada pertemuan 1 berjumlah 19 orang dengan persentase $76 \%$ dan pada pertemuan 2 terjadi peningkatan yaitu sebanyak 20 orang yang berdiskusi dengan persentase sebesar $80 \%$, dari kedua hasil indikator tersebut di dapat rata-rata persentase sebesar 78\%. Pada siklus II ini terjadi peningkatan mencapai $70 \%$ yang telah di tetapkan. Siswa yang bertanya dan menjawab pertanyaan pada pertemuan 1 berjumlah 17 orang dengan persentase $68 \%$, sedangkan pada pertemuan 2 siklus II siswa yang berdiskusi berjumlah 18 orang dengan persentase $72 \%$. Jadi diperoleh rata-rata persentase $70 \%$ dalam kategori banyak.

Siswa yang memberikan kesimpulan pada pertemuan 1 siklus II berjumlah 18 orang dengan persentase $72 \%$, sedangkan pada pertemuan 2 siklus II siswa yang memberikan kesimpulan berjumlah 20 orang dengan persentase $80 \%$. Jadi diperoleh rata-rata persentase $76 \%$ dalam kategori banyak sekali.
2. Data hasil observasi aktivitas guru

Berdasarkan lembar observsi aktivitas guru dalam pembelajaran pada siklus II, maka jumlah skor dan persentase aktivitas guru dalam mengelola pembelajaran pada siklus II dapat dilihat pada tabel berikut:

Tabel 05.

Persentase Observasi Aktivitas Guru pada Siklus II

\begin{tabular}{|c|c|c|c|c|}
\hline $\begin{array}{l}\text { Pertem } \\
\text { uan }\end{array}$ & $\begin{array}{l}\text { Skor } \\
\text { Iaksimal }\end{array}$ & $\begin{array}{l}\text { Jumlah } \\
\text { Skor }\end{array}$ & $\begin{array}{l}\text { Persentas } \\
\mathrm{e}\end{array}$ & $\begin{array}{l}\text { Kateg } \\
\text { ori }\end{array}$ \\
\hline 1 & 80 & 69 & $86,25 \%$ & $\begin{array}{l}\text { Sanga } \\
\text { t Baik }\end{array}$ \\
\hline 2 & 80 & 71 & $88,75 \%$ & $\begin{array}{l}\text { Sanga } \\
\text { t Baik }\end{array}$ \\
\hline \multicolumn{2}{|c|}{ Rata-rata } & 70 & $87,5 \%$ & $\begin{array}{l}\text { Sanga } \\
\text { t Baik }\end{array}$ \\
\hline
\end{tabular}

Dari tabel di atas, dapat dilihat bahwa persentase guru dalam mengelola pembelajaran memiliki rata-rata persentase $87,5 \%$ mencapai rata-rata $70 \%$, sehingga guru dalam mengelola pembelajaran sudah dapat dikatakan baik dan meningkat dari siklus sebelumnya.

\section{Data Hasil Belajar pada Ujian Akhir Siklus II}

Berdasarkan hasil tes siklus II, persentase siswa yang tuntas tes akhir siklus, dan rata-rata skor tesnya dapat dilihat pada tabel berikut:

Tabel 06. Ketuntasan dan Rata- rata Tes Hasil Belajar Siswa siklus.

\begin{tabular}{|l|l|l|l|}
\hline No & Uraian & Jumlah & Persentase \\
\hline 1. & $\begin{array}{l}\text { Jumlah siswa yang } \\
\text { mengikuti tes }\end{array}$ & 25 & $100 \%$ \\
\hline
\end{tabular}


303 Peningkatan Aktivitas Belajar Siswa melalui Model Think Pair Share di Sekolah Dasar - Maria Ratna Sariayu, Yalvema Miaz

\begin{tabular}{|l|l|l|l|}
\hline 2. & $\begin{array}{l}\text { Jumlah siswa yang } \\
\text { tuntas belajar }\end{array}$ & 18 & $72 \%$ \\
\hline 3. & $\begin{array}{l}\text { Jumlah siswa yang } \\
\text { tidak tuntas belajar }\end{array}$ & 7 & $28 \%$ \\
\hline 4. & $\begin{array}{l}\text { Persentase } \\
\text { ketuntasan belajar } \\
\text { siswa }\end{array}$ & $72 \%$ \\
\hline 5. & Rata-rata skor siswa & 75,4 \\
\hline
\end{tabular}

Dari tabel di atas dapat disimpulkan, apabila dibandingkan dengan siklus I, maka siklus II ini jauh lebih baik. Hal ini terlihat pada persentase ketuntasan belajar dan rata-rata skor tes. Pada siklus I terdapat $24 \%$ siswa yang tuntas belajar dengan rata-rata skor tes $44 \%$. Sedangkan pada siklus II terdapat $72 \%$ siswa yang tuntas belajar dengan rata-rata skor tes 75,4. Dapat ditarik kesimpulan bahwa pada siklus II, siswa sudah dapat dikatakan tuntas belajar secara klasikal dengan rata-rata skor tes juga meningkat. Hal ini sudah menunjukkan tercapainya target pembelajaran yang diinginkan yaitu $70 \%$.

Pembelajarandengan menggunakan model Think Pair Share merupakan hal baru bagi siswa. Dalam pelaksanaannya peneliti menemui berbagai masalah terutama dalam pengelolaan kelas, Untuk mengatasi hal ini, peneliti melakukan tahap perencanaan dan pelaksanaan pembelajaran menggunakan model Think Pair Share. setelah menggunakan model Think Pair Share siswa dapat menunjukkan aktivitas yang baik secara keseluruhan, yang pada akhirnya akan meningkatkan hasil belajar siswa. Hal tersebut dapat dijelaskan seperti dibawah ini.
Tabel 07: Persentase Rata-Rata Aktivitas Siswa Pada Siklus I dan Siklus II

\begin{tabular}{|c|c|c|c|c|c|}
\hline \multicolumn{6}{|c|}{ Rata-rata Persentase } \\
\hline No & $\begin{array}{l}\text { Indikator } \\
\text { Aktivitas } \\
\text { Siswa }\end{array}$ & Siklus I & $\begin{array}{l}\text { Siklus } \\
\text { II }\end{array}$ & Target & $\begin{array}{l}\text { Keter } \\
\text { angan }\end{array}$ \\
\hline 1 & $\begin{array}{l}\text { Siswa } \\
\text { diskusi }\end{array}$ & $50 \%$ & $78 \%$ & $70 \%$ & $\begin{array}{l}\text { Banya } \\
\mathrm{k} \\
\text { sekali }\end{array}$ \\
\hline 2 & $\begin{array}{l}\text { Siswa } \\
\text { bertanya } \\
\text { dan } \\
\text { menjawab } \\
\text { pertanyaaan }\end{array}$ & $44 \%$ & $70 \%$ & $70 \%$ & $\begin{array}{l}\text { Banya } \\
\mathrm{k}\end{array}$ \\
\hline 3 & $\begin{array}{l}\text { Siswa } \\
\text { memberikan } \\
\text { kesimpulan }\end{array}$ & $42 \%$ & $76 \%$ & $70 \%$ & $\begin{array}{l}\text { Banya } \\
\mathrm{k}\end{array}$ \\
\hline & $\begin{array}{l}\text { Rata-rata } \\
\text { aktivitas } \\
\text { siswa }\end{array}$ & 45,33 & $74,60 \%$ & $70 \%$ & $\begin{array}{l}\text { Banya } \\
\mathrm{k}\end{array}$ \\
\hline & $\begin{array}{l}\text { Rata-rata } \\
\text { aktivitas } \\
\text { guru }\end{array}$ & 75,63 & $87,50 \%$ & $70 \%$ & $\begin{array}{l}\text { Banya } \\
\mathrm{k} \\
\text { sekali }\end{array}$ \\
\hline & $\begin{array}{l}\text { rata- rata tes } \\
\text { akhir siklus }\end{array}$ & 75,63 & $72 \%$ & $70 \%$ & $\begin{array}{l}\text { Banya } \\
\mathrm{k}\end{array}$ \\
\hline
\end{tabular}

Berdasarkan tabel tersebut, dapat disimpulkan bahwa pembelajaran IPS menggunakan model Think Pair Share yang dilaksanakan dapat terjadi peningkatan aktivitas siswa. Hal ini terbukti rata-rata persentase untuk aktivitas siswa berdiskusi pada siklus I sebanyak $50 \%$, terjadi peningkatan pada siklus II sebesar $78 \%$. Pada siklus II ini mengalami peningkatan mencapai $70 \%$

Rata-rata persentase siswa yang bertanya dan menjawab pertanyaan pada siklus I sebanyak $44 \%$, mengalami peningkatan pada siklus II sebesar 70\%. Pada siklus II ini telah terjadi peningkatan mencapai $70 \%$ yang telah ditetapkan.

Untuk rata-rata persentase siswa dalam memberikan kesimpulan pada siklus I sebanyak $42 \%$, mengalami peningkatan pada siklus II mencapai 76\%. Pada siklus II ini mengalami peningkatan mencapai $70 \%$ yang telah ditetapkan. 
304 Peningkatan Aktivitas Belajar Siswa melalui Model Think Pair Share di Sekolah Dasar - Maria Ratna Sariayu, Yalvema Miaz

Keberhasilan siswa dalam pembelajaran pada umumnya dilihat juga dari pengelolaan pelaksanaan pembelajaran pada persentase aktivitas guru. Dalam hal ini terlihat peningkatan dari siklus I ke siklus II. Persentase aktivitas guru dapat dilihat pada tabel 08 dibawah ini:

Tabel 08.

Persentase Aktivitas Guru pada Siklus I dan Siklus

II

\begin{tabular}{|c|l|l|}
\hline No & Siklus & -rata Per Siklus \\
\hline 1. & I & $75,63 \%$ \\
\hline 2. & II & $87,5 \%$ \\
\hline 3. & $\begin{array}{l}\text { Rata-rata } \\
\text { persentase }\end{array}$ & $81,57 \%$ \\
\hline \multicolumn{2}{|l|}{ Dari tabel diatas dapat disimpulkan bahwa }
\end{tabular}

Dari tabel diatas dapat disimpulkan bahwa pelaksanaan pembelajaran menggunakan model Think Pair Share pada siklus I dapat dilihat ratarata persentase $75,63 \%$ dapat dikatakan baik. Hal ini disebabkan guru belum terbiasa membawakan pembelajaran menggunakan model Think Pair Share, dan baru pertama kali dicobakan oleh guru. Pada siklus II dapat dilihat rata-rata persentase $87,5 \%$ dapat dikatakan sangat baik, hal ini disebabkan guru sudah mulai terbiasa menggunakan model Think Pair Share, sehingga pelaksanaan pembelajaran lebih meningkat dibandingkan siklus I.

\section{SIMPULAN}

Berdasaran hasil penelitian dan pembahasan sebelumnya, peneliti dapat menyimpulkan sebagai berikut: Pada pembelajaran IPS melalui model Think Pair Share dapat meningkatkan aktivitas belajar siswa, untuk indikator aktivitas siswa berdiskusi, rata-rata persentase pada siklus I adalah $50 \%$, sedangkan pada siklus II rata-rata persentase mencapai $78 \%$.. Pada pembelajaran IPS melalui model Think Pair Share dapat meningkatkan aktivitas belajar siswa, untuk indikator aktivitas siswa bertanya dan menjawab pertanyaan, rata-rata persentase pada siklus I adalah 44\%, sedangkan pada siklus II ratarata persentase mencapai $70 \%$.. Pada pembelajaran IPS melalui model Think Pair Share dapat meningkatkan aktivitas belajar siswa, untuk indikator aktivitas siswa memberikan kesimpulan, rata-rata persentase pada siklus I adalah $42 \%$, sedangkan pada siklus II rata-rata persentase mencapai $76 \%$, dari perbandingan kedua siklus tersebut terdapat peningkatan, hal ini berarti bahwa aktivitas siswa pada pembelajaran IPS sudah meningkat dari sebelumnya.

\section{DAFTAR PUSTAKA}

Arikunto, Suharsimi, dkk. 2010. Penelitian Tindakan Kelas. Jakarta: Bumi Aksara.

Bungin, Burhan. 2003. Analisis Data Penelitian Kualitatif. Jakarta: Grafindo Persada.

Desfitri, Rita. 2008. Laporan Pengembangan Inovasi Pembelajaran di Sekolah. Padang:Universitas Bung Hatta.

Istarani. 2012. 58 Model Pembelajaran Inovatif. Medan: Media Persada.

Ketut, S. (2018). Pengaruh Model Pembelajaran Kooperatif Tipe Think Talk Write (TTW) Terhadap Hasil Belajar dan Kemampuan Berpikir Kritis pada Pembelajaran IPA di Sekolah Dasar. Jurnal Widyacarya, 2(2), 1924.

Situmorang, L. (2018). Penerapan Metode Tanya Jawab Dalam Memperbaiki Hasil Belajar Siswa Pada Ips Kelas Iv Sd Negeri 060819 Medan. Elementary School Journal Pgsd Fip Unimed, $8(2)$, 76-85.

https://doi.org/10.24114/esjpgsd.v8i2.10375 
305 Peningkatan Aktivitas Belajar Siswa melalui Model Think Pair Share di Sekolah Dasar - Maria Ratna Sariayu, Yalvema Miaz

Tarbiyah, F., Raden, I., Palembang, F., Abidin, Z., \& No, F. (2011). Model Pembelajaran Kooperatif Tipe Think Pair Share Dan Hasil Belajar Di Sekolah. Ta'dib, 16(02), 303-319.

Yalvema, M. (2012). Aplikasi Pendekatan Pembelajaran Kooperatif Tipe Jigsaw Untuk Meningkatkan Proses dan Hasil Belajar IPS Siswa Kelas V Sekolah Dasar Negeri 01 Beringin Anam Baso Kabupaten Agam. Dalam laporan penelitian Bidang pendidikan IPS SD. PGSD-FIP:UNP.

Suryosubroto, B.2010. Beberapa Aspek DasarDasar Kependidikan. Jakarta: Rineka Cipta

Purwanto. 1985. Ilmu Pendidikan Teoritis dan Praktis. Bandung: Remadja Karya 